\title{
Curcumin in combination: Review of synergistic effects and mechanisms in the treatment of inflammation
}

\author{
Putu Yudhistira Budhi Setiawan ${ }^{1,2 *}$, Nyoman Kertia ${ }^{3}$, Arief Nurrochmad ${ }^{4}$, Subagus Wahyuono ${ }^{5}$ \\ ${ }^{1}$ Doctoral Program of the Faculty of Pharmacy, Universitas Gadjah Mada, Yogyakarta, 55281, Indonesia. \\ ${ }^{2}$ Department of Clinical Pharmacy, Faculty of Heatlh Sciences, Universitas Bali Internasional, Denpasar, 80239, Indonesia. \\ ${ }^{3}$ Department of Internal Medicine, Faculty of Medicine, Public Health and Nursing, Universitas Gadjah Mada, Yogyakarta, 55281, Indonesia. \\ ${ }^{4}$ Department of Pharmacology and Clinical Pharmacy, Faculty of Pharmacy, Universitas Gadjah Mada, Yogyakarta, 55281, Indonesia. \\ ${ }^{5}$ Department of Pharmaceutical Biology, Faculty of Pharmacy, Universitas Gadjah Mada, Yogyakarta, 55281, Indonesia.
}

\section{ARTICLE INFO \\ Received on: 03/11/2020 \\ Accepted on: 03/01/2021 \\ Available online: 05/02/2021}

\section{Key words:}

Curcumin, combination, anti-inflammation, synergis.

\begin{abstract}
Inflammation has an important role in the pathology of various diseases, so it has become a therapeutic target for the development of new pharmacological treatments. Treatment of inflammation using non-steroidal anti-inflammatory drugs and steroids class of drugs is known to incur some side effects. Therefore, prevention of inflammation is key to preventing the severity level of the disease. One approach to bridge this problem is by synergistically combining two or more drugs to prevent inflammation. The anti-inflammatory effect of curcumin, a bioactive component especially in the Zingiberaceae family, which delivers a variety of health benefits, has been extensively researched in the last few decades. Curcumin combination has been reported to increase the anti-inflammatory activities. A literature review on researches regarding curcumin combination through some electronic databases, including PubMed and Google Scholar on the combined information, has been carried out. In this review, we summarize the pharmacological activity of curcumin in combination with other components, in particular on synergistic anti-inflammatory effects. To understand how combinations provide a synergistic effect, we present increased bioavailability, which increases the capacity of antioxidants to inhibit inflammatory mediators, receptors, and major signaling pathways. This review provides information and encourages more research in combining medicinal compounds to reduce inflammation.
\end{abstract}

\section{INTRODUCTION}

Inflammatory disease is known to have more than 200 types. The names of diseases ending with "itis" indicate the occurrence of inflammation. Acute inflammation is considered to be a defense mechanism because it helps with healing, but inflammation of chronic diseases such as cholangitis can lead to colon cancer. Inflammation if not treated will aggravate various chronic diseases, such as autoimmune, endocrine, neurodegenerative, and cardiovascular diseases, because it is involved in the development of these diseases (Chen et al., 2018). The molecular mechanisms that cause inflammation have

\section{"Corresponding Author}

Putu Yudhistira Budhi Setiawan, Department of Clinical Pharmacy, Faculty of Heatlh Sciences, Universitas Bali Internasional, Denpasar, 80239, Indonesia. E-mail:yudhistirabudhi@gmail.com been investigated, and various enzymes, cytokines, chemokines, and polypeptide hormones that can mediate inflammation have been identified. These include tumor necrosis factor (TNF), IL-1 $\alpha$, interleukin-1 $\beta$ (IL-1 $\beta$ ), IL-6, interleukin-8 (IL-8), IL18, chemokine, Matrix metallopeptidase 9 (MMP-9), vascular endothelial growth factor (VEGF), cyclooxygenase-2 (COX-2), and 5-lipoxygenase (5-LOX). Monocytes, neutrophils, eosinophils, and mast cells, if the numbers are not controlled, will recruit more immune cells to create more proinflammatory molecules. The consequence will be various types of chronic diseases because the process produces nitric oxide (NO) and reactive oxygen species (ROS), which are responsible for damage to the structure, function, integrity of lipids, proteins, and nucleic acids (Ben-Baruch, 2006).

The expression of this gene is highly regulated by the transcription factor of nucleus- $\kappa \beta$ (NF- $\kappa \beta$ ) (Aggarwal et al., 2013). The NF- $\kappa \beta$ pathway is responsible for chronic inflammation as it triggers the release of various types of cytokines, chemokines, 
adhesion molecules, and leukocyte recruitment, thereby weakening the NF- $\kappa \beta$ pathway as a strategy for treating chronic inflammation (Lawrence, 2009). Anti-inflammatory drugs temporarily suppress the symptoms of inflammation, but the disease continues to develop over time and drugs, such as non-steroidal anti-inflammatory drugs, can increase the risk of adverse gastrointestinal, renal, and cardiovascular effects (Bacchi et al., 2012; Tai et al., 2018). Antiinflammatory corticosteroid drugs have a strong therapeutic effect for various disorders, but long-term use also incurs side effects (Buchman, 2001; Oray et al., 2016).

Curcumin is a secondary metabolite found in many rhizomes of the Curcuma longa and Zingiberaceae family as a medicinal herb for antioxidant and anti-inflammatory properties (Lestari et al., 2014; Surh et al., 1998). There has been a widely spread use of curcumin as traditional medicine until now. Curcumin, 1, 7-bis (4-hydroxy-3-methoxyphenyl)1,6-heptadien-3,5-dione, and the yellow pigment in turmeric rhizome are used as medicine and there have been various studies developed to understand their use, especially in the Asian region (Noorafshan et al., 2013; Thakur et al., 1989). Curcumin has pharmacological effects on reducing inflammation because it interacts with many inflammatory pathways and mechanisms. Research reveals that curcumin has various health benefits, including activity to reduce inflammation, antioxidants, chemopreventive, and chemotherapy (Pulido-Moran et al., 2016). The pharmacological activity has been demonstrated in cultured cells, animal models, and human clinical trials (Hatcher et al., 2008). Compound combination studies provide opportunities for therapeutic problems of overcoming drug resistance and toxicity (Bulusu et al., 2016). A combination of drugs is used to treat severe and chronic diseases. This combination provides many advantages in treatment including achieving a synergistic therapeutic effect, reducing the dosage used so that toxicity will be reduced, and minimizing or delaying the induction of drug resistance (Chou, 2010).

This review aims to investigate the combination of curcumin with two or more other drugs and how this combination can synergistically provide an anti-inflammatory effect rather than a single use. In this review, we summarize the anti-inflammatory effects that arise from the combination of various components with curcumin, especially the results of the synergistic antiinflammatory effect. The benefits of this review provide scientific information regarding the combined effects when curcumin is combined with other components to suppress inflammation. The results of this review are expected to provide information on strategies for handling inflammation, with a synergistic effect between components, so as to provide effective treatment with minimal side effects.

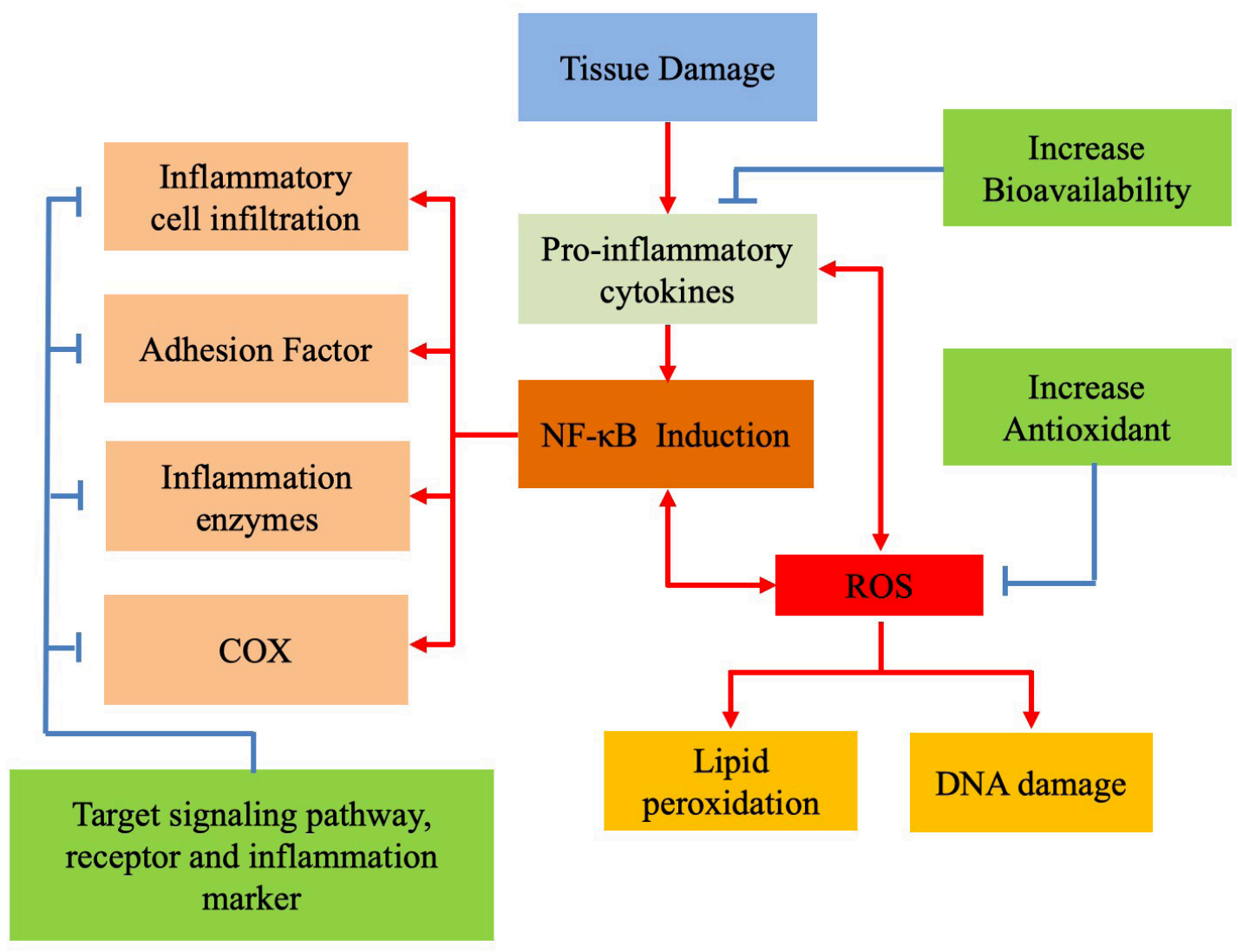

Figure 1. The mechanism of the combined synergistic anti-inflammatory effect of curcumin through various mechanisms increases bioavailability by regulating metabolism. The combination can directly increase antioxidants to fight ROS. Reduced ROS can attenuate the $\mathrm{NF}-\kappa \beta$ pathway and then regulate the transcription and translation of the proinflammatory marker. This altered molecule will suppress the proliferation and migration of immune cells and maintain the integrity of endothelial cells to further reduce the production of proinflammatory markers that ultimately inhibit inflammation (Zhang et al.,2019). 


\section{METHOD}

A systematic search was conducted to find all publications related to the topic up to August 2020 on PubMed and Google Scholar databases. "Curcumin, combination, and anti-inflammatory" were used as the keywords used to find the related articles. The inclusion criteria in this review were articles using a combination of curcumin components (drugs or phytochemicals) that can provide anti-inflammatory effects, comparing the effects of curcumin alone with a combination, and articles that produce anti-inflammatory effects that are synergistic or better than using curcumin alone. Some published articles in English were selected based on the criteria that these articles provide comparative data between the single use of curcumin and its combination. Articles were excluded from primary articles if they were conference articles, review articles, and thesis. All synthetic derivatives of curcumin are not mentioned in this review. Articles searched until August 2020 found 55 main articles and 36 types of components combined with curcumin (Table 1). These selected articles were written based on in vitro and in vivo experiments on curcumin and its combination. After selecting these articles, we conducted a review by mainly assessing the types of test animals, cells, the induction compound used, and the effects of these combinations.

\section{Determination of the effects of a combination}

The combination of more than one type of drug component is often used in medicine. A particular strategy does not always enhance its specific pharmacological effect; combinations involving two or more components can provide additive, synergistic, or antagonistic effects. The Chou-Talalay method has been used in combination with drug studies worldwide and evaluations of its effects. The combination index (CI), where $\mathrm{CI}=1$, indicates additive effect, $\mathrm{CI}<1$ synergism, and $\mathrm{CI}>1$ antagonism (Chou, 2006). Based on our exploration, this method is widely used for drug combination studies. Combination of index calculation was carried out using the following formula:

$$
\mathrm{CI}=\frac{(D) 1}{(D m) 1}+\frac{(D) 2}{(D m) 2}
$$

$(D) 1$ and $(D) 2$ are the concentrations of components $\mathrm{X}$ and $\mathrm{Y}$ which are combined to produce a value of $\mathrm{IC}_{50^{\circ}}(\mathrm{Dm}) 1$ and $(D m) 2$ are the concentrations of components $\mathrm{X}$ and $\mathrm{Y}$ given singly and obtained the value of $\mathrm{IC}_{50}$. Determination of the combined effect in test animals followed the same principle as that in CI. However, combination studies reveal that drugs have some limitations, such as being more expensive, more timeconsuming, having limited group, and population limitations. In this review, we got to measure the combined effect of in vitro using a comparison between the combined effect of the drug with those uncombined. The effect was obtained by a simple formula of $\mathrm{X}+\mathrm{Y}>\mathrm{X}$ or $\mathrm{X}+\mathrm{Y}>\mathrm{Y}$. In clinical trial research, if treatment using a drug combination gives a better pharmacological effect than monotherapy, it can be concluded that it has a synergistic effect (Chou, 2010). In this review, it is known that the CI method has been used in several in vitro studies. Studies using test animals obtained the synergy effect based on a comparison between combination and single use, and only the curcumin combination with a synergistic anti-inflammatory effect was discussed.

\section{Effect of curcumin on anti-inflammation}

Curcumin has been known to have various pharmacological activities, in particular as anti-inflammatory properties. Curcumin is known for its ability to suppress acute and chronic inflammation (Noorafshan et al., 2013). Curcumin can work through various mechanisms either singly or in combination. The mechanism of curcumin as an anti-inflammatory includes the inhibition of arachidonic acid metabolic processes, COX and LOX pathways, and decreases prostaglandin synthesis. Curcumin specifically inhibits COX-2 expression (Goel et al., 2001; Kunnumakkara et al., 2009; Zhang et al., 1999). Curcumin has more active activity against the COX-2 enzyme when compared to the COX-1 enzyme (Ramsewak et al., 2000). Curcumin can prevent anti-inflammatory responses in synovial fibroblasts by inhibiting prostaglandin E2 synthesis (PGE2) and suppressing COX-2 (Moon et al., 2010). The anti-inflammatory effect of curcumin is also seen in 5-LOX inhibition on rat peritoneal neutrophils and cyclooxygenase activity on human platelets (Ammon et al., 1993). The activity of curcumin as suppressing inflammation has been shown in in vitro and in vivo studies because it can reduce the production of proinflammatory cytokine IL-8, inflammatory protein monocyte-1, chemotactic protein monocyte-1 (MCP-1), IL-1 $\beta$, and tumor necrosis factor- $\alpha$ (TNF- $\alpha$ ) (Anthwal et al., 2014; Gupta et al., 2014; Hong et al., 2004).

The effects of high glucose and secretion of IL-6, IL-8, MCP-1, and TNF- $\alpha$ are inhibited by curcumin in cultured monocytes (Jain et al., 2009). Another study using curcumin has shown its activity as a powerful asthma reliever. This effect is due to the mechanism of inhibiting the production of IL-2, IL-4, and IL-5 and reducing immunoglobulin E2 (Chung et al., 2012; Kobayashi et al., 1997). Curcumin also has anti-inflammatory activity in pancreatitis rats by regulating the expression of $\mathrm{NF}-\kappa \beta$, activator protein 1 , inducible nitric oxide synthase (iNOS), TNF- $\alpha$, and IL-6 (Gulcubuk et al., 2013). The ability of curcumin to inhibit the mitogen-activated protein kinase (MAPK) and NF- $\kappa \beta$ pathways was shown in the in vitro test; curcumin also inhibits IL- 6 and TNF- $\alpha$ in BV2 microglia cells stimulated with lipopolysaccharide (Cho et al., 2007; Jin et al., 2007).

Curcumin activity can reduce inflammation by reducing the formation of ROS and increasing enzymatic activity, such as methionine sulfoxide reductase A expression. It also increases enzymes such as superoxide dismutase (SOD), catalase (CAT), and glutathione peroxidase (GPx) (Dai et al., 2015; Meshkibaf et $a l ., 2019)$. The use of curcumin in thallium acetate-induced rats at a dose of $200 \mathrm{mg} / \mathrm{kg}$ can contribute to increasing SOD activity, CAT, and total liver antioxidant capacity (Abdel-Daim et al., 2015). Curcumin has antioxidant activity so it can act as an NO scavenger and as an oxidative DNA cleaving agent (Ahsan et al., 1999; Nilani et al., 2009). The expression of the iNOS gene in $\mathrm{BALB} / \mathrm{c}$ mice isolated from peritoneal macrophages and livers of mice injected with lipopolysaccharide (LPS) is also inhibited after receiving curcumin (Chan et al., 1998). Curcumin can inhibit NO production, iNOS, and messenger ribonucleic acid (mRNA) protein expression in RAW 264.7 cells stimulated with lipopolysaccharide or interferon- $\gamma$ (Fu et al., 2016). Curcumin has been shown to have activity in inhibiting lipid peroxidation, a process that is found in rat liver microsomes (Reddy et al., 1992). Similarly, in rat brain homogenates, curcuminoids show antioxidant activity (Sreejayan et al., 1994). 
Table 1. Synergistic effect of combining curcumin as anti-inflammatory.

\begin{tabular}{|c|c|c|c|c|c|}
\hline No. & Component & Pharmacology model & Induction/treatment & Result & Reference \\
\hline \multirow[t]{8}{*}{1} & Piperine & Male Swiss albino mice & LPS & $\begin{array}{l}\text { Suppresses proinflammatory cytokines (IL-1 } \beta \\
\text { and TNF- } \alpha \text { ) }\end{array}$ & (Jangra et al., 2016) \\
\hline & & Male Wistar mouse & Olfactory bulbectomy model & Lower brain TNF- $\alpha$ and caspase 3 levels & (Rinwa et al., 2013) \\
\hline & & Male C57BL/6J mice & High fat & $\begin{array}{l}\text { Downregulates proinflammatory cytokines (IL- } 6 \\
\text { and TNF } \alpha \text { ) }\end{array}$ & (Neyrinck et al., 2013) \\
\hline & & Epithelial cells HT-29 & TNF- $\alpha$ & Inhibits TNF- $\alpha$ and COX-2 & (Kaur et al., 2018) \\
\hline & & Albino Wistar Rat & - & Increases bioavailability & (Shoba et al., 1998) \\
\hline & & Male C57BL/6 mice & High fat & Suppresses proinflammatory cytokines IL- $1 \beta$ & (Miyazawa et al., 2018) \\
\hline & & Male Wistar rats & Haloperidol & Inhibits NO, TNF- $\alpha$, and NF- $\kappa \beta$ & (Bishnoi et al., 2011) \\
\hline & & RAW 264.7 & RANKL & Inhibit osteoclastogenesis & (Martins et al., 2015) \\
\hline \multirow[t]{9}{*}{2} & Resveratrol & Male Wistar rats & Fipronil & $\begin{array}{l}\text { Increases glutathione (GSH), GPx, SOD, and } \\
\text { CAT; malondialdehid (MDA) and NO decrease }\end{array}$ & (A1 Basher et al., 2020) \\
\hline & & Chondrocyte & IL-1 $\beta$ & $\begin{array}{l}\text { Inhibits expression IL-1 } \beta, \text { COX-2, MMP-3, } \\
\text { MMP-9, and VEGF }\end{array}$ & (Csaki et al., 2009) \\
\hline & & Colon cancer HCT-116 & - & $\begin{array}{l}\text { Reduces proliferation and stimulation of } \\
\text { apoptosis accompanied by attenuation of NF- } \kappa \beta \\
\text { activity }\end{array}$ & (Majumdar et al., 2009) \\
\hline & & HO radical & - & $\begin{array}{l}\text { Resveratrol is able to protect curcumin from } \\
\text { degradation }\end{array}$ & (Coradini et al., 2014) \\
\hline & & Male rat Wistar & complete Freund's adjuvant (CFA) & Reduces paw thickness and arthritis score & (Coradini et al., 2015) \\
\hline & & Male Laka mice & Benzo[a]pyrene & $\begin{array}{l}\text { Brings down the enzyme activity of COX-2, } \\
\text { significantly improved protein expressions of p } 21\end{array}$ & (Malhotra et al., 2011) \\
\hline & & Weaned piglets & - & Inhibits IL- $1 \beta$ and TNF- $\alpha$ & (Gan et al., 2019) \\
\hline & & Male Wistar rats & Cotton ligature & Inhibits IL- $1 \beta$ and IL-4 & (Corrêa et al., 2017) \\
\hline & & Male adult Wistar & Aluminum chloride & $\begin{array}{l}\text { Inhibits COX-2 and increase SOD, GSH, CAT, } \\
\text { and glutathione S-transferase }\end{array}$ & (Zaky et al., 2017) \\
\hline \multirow[t]{3}{*}{3} & Quercetin & Male albino rats & Carrageenan & $\begin{array}{l}\text { Increases GSH levels and HO- } 1 \text { mRNA } \\
\text { expression, reducing paw thickness, induced } \\
\text { elevation in MDA, NO, and TNF- } \alpha\end{array}$ & (Heeba et al., 2014) \\
\hline & & Albino rat & Diazinon & $\begin{array}{l}\text { Increases antioxidant parameters (GSH and GPx } \\
\text { SOD, and CAT) }\end{array}$ & (Abdel-Diam et al., 2019) \\
\hline & & K562 cells & - & Inhibits total NO, NF- $\kappa \beta$, and COX-2 & (Güran et al., 2019) \\
\hline 4 & Puerarin & Male Sprague Dawley rat & LPS & Reduces IL-1 and MMP-9; increases IL-10 & (Singh et al., 2013) \\
\hline 5 & Turmeron & Male rats & dimethylhydrazine & $\begin{array}{l}\text { Reduces expression of iNOS and COX-2, } \\
\text { decreasing NF- } \kappa \beta \text { transcription activity }\end{array}$ & (Murakami et al., 2013) \\
\hline 6 & Fish oil & Mice & dextran sulfate sodium (DSS) & $\begin{array}{l}\mathrm{NF}-\kappa \beta \text { activity and inflammatory score in the } \\
\text { colonic mucosa }\end{array}$ & (Jia et al., 2011) \\
\hline 7 & $\begin{array}{l}\text { Rhizoma Paridis } \\
\text { saponins }\end{array}$ & Male Sprague Dawley rat & - & $\begin{array}{l}\text { Reduces COX-2, IL- } 1 \beta \text {, NF- } \kappa \beta \text {, enhancement of } \\
\text { HO-1, GSH, SOD, and Nrf2 activities }\end{array}$ & (Man et al., 2016) \\
\hline 8 & $\begin{array}{l}\text { Hydrolyzed collagen and } \\
\text { green tea extract }\end{array}$ & $\begin{array}{l}\text { Osteoarthritic human } \\
\text { chondrocytes }\end{array}$ & IL-1 $\beta$ & Reduces NO, MMP-3, and IL-6 & (Comblain et al., 2015) \\
\hline 9 & Emu oil & Male Sprague Dawley rat & Carrageenan and CFA & $\begin{array}{l}\text { Inhibits paw volume, reduces TNF- } \alpha \text {, IL- } 6 \text {, and } \\
\text { IL- } 1 \beta\end{array}$ & (Jeengar et al., 2014) \\
\hline 10 & Vitamin E & Mice & High calorie & $\begin{array}{l}\text { Increases activity (GPx) and Nrf-1 and reduces } \\
\text { lobular inflammatory score and numeric analog } \\
\text { scale score }\end{array}$ & (Heritage et al., 2017) \\
\hline 11 & $\begin{array}{l}\text { Vitamin B2, carnitine, } \\
\text { and N-acetyl-cysteine }\end{array}$ & 16HBE cell & Cigarette smoke extract & $\begin{array}{l}\text { Decreases the inflammatory cytokine gene IL- } 1 \beta \text {, } \\
\text { IL- } 6, T N F \alpha \text {, and NOS }\end{array}$ & (Vanella et al., 2017) \\
\hline 12 & Berberine & Male Sprague Dawley rats & High calorie & $\begin{array}{l}\text { Decreases expression of Sterol regulatory } \\
\text { element-binding transcription factor 1, protein } \\
\text { extracellular signal-regulated kinase, TNF- } \alpha \text {, and } \\
\text { protein c-Jun N-terminal kinase }\end{array}$ & (Feng et al., 2018) \\
\hline 13 & Vitamin D3 & Adult female Wistar rats & High calorie & $\begin{array}{l}\text { Reduces arthritis score and myeloperoxidase } \\
\text { activity }\end{array}$ & (da Silva et al., 2019) \\
\hline 14 & Ursodeoxycholic acid & Rat & NAFLD & $\begin{array}{l}\text { Increases total antioxidant capacity, GSH, GPx, } \\
\text { and SOD; decreases MDA levels and iNOS } \\
\text { expression }\end{array}$ & (Gheibi et al., 2019) \\
\hline 15 & Ursolic acid & Female ICR mice & tissue plasminogen activator (TPA) & $\begin{array}{l}\text { Inhibits the expression of IL- } 1 \beta \text {, IL- } 6 \text {, IL-19, } \\
\text { IL-22, cemokine ligand } 2 \text { (CXCL2), COX-2, and } \\
\text { VEGFA }\end{array}$ & (Tremmel et al., 2019) \\
\hline
\end{tabular}




\begin{tabular}{|c|c|c|c|c|c|}
\hline No. & Component & Pharmacology model & Induction/treatment & Result & Reference \\
\hline 16 & Boswellic acids & Rat & CFA & $\begin{array}{l}\text { Reduces paw volume, but does not significantly } \\
\text { reduce TNF- } \alpha \text { and IL- } 6\end{array}$ & (Khayyal et al., 2018) \\
\hline 17 & Salidroside & Rat & LPS & Reduce in the IL- 6 and TNF- $\alpha$ & (Vasileva et al., 2018) \\
\hline 18 & Silymarin & Male Wistar albino rat & Gamma radiation & $\begin{array}{l}\text { Decreases the level of IL-18, TNF- } \alpha \text {, C-reactive } \\
\text { protein, Bax, factor-related apoptosis, and the } \\
\text { activity of Casp-3 }\end{array}$ & (Abdel-Magied et al., 2019) \\
\hline \multirow[t]{2}{*}{19} & \multirow[t]{2}{*}{ Prednisolone } & Rat & Adjuvant-induced arthritis & $\begin{array}{l}\text { Reduces TNF- } \alpha \text {, IL- } 1 \beta \text {, and IL- } 6 \text { and increase } \\
\text { IL-10 }\end{array}$ & \multirow[t]{2}{*}{ (Yan et al., 2019) } \\
\hline & & RAW 264.7 & LPS & $\begin{array}{l}\text { Reduce TNF- } \alpha \text {, IL- } 1 \beta \text {, and IL- } 6 \text { and increases } \\
\text { IL-10 }\end{array}$ & \\
\hline 20 & Thymoquinone & Sprague Dawley rats & Cisplatin & Reduces TNF- $\alpha$, IL- 6 , and MCP-1 & (Al Fayi et al., 2020) \\
\hline 21 & Flavocoxid & Chondrocytes & LPS & $\begin{array}{l}\text { Reduces IL- } 1 \beta \text { of NF- } \kappa \beta \text { and sgnal transducer } \\
\text { and activator of transcription } 3 \text { mRNA } \\
\text { expression }\end{array}$ & (D’Ascola et al., 2019) \\
\hline 22 & Tolfenamic acid & Female BALB/c mice & TPA & $\begin{array}{l}\text { Reduces levels of COX-2 and inhibition of IKK } \\
\text { and NF- } \kappa\end{array}$ & (Zhou et al., 2020) \\
\hline 23 & Luteolin & Male C57BL/6 mice & TNF- $\alpha$ & Reduces TNF- $\alpha$ vascular inflammation & (Lijuan et al., 2019) \\
\hline 24 & $\begin{array}{l}\text { Polyunsaturated fatty } \\
\text { acid }\end{array}$ & RAW 264.7 cells & LPS & $\begin{array}{l}\text { Suppresses iNOS, COX-2, 5-lipoxygenase, and } \\
\text { cytosolic phospholipase A2 }\end{array}$ & (Saw et al., 2010) \\
\hline 25 & Sulforaphane & RAW 264.7 cells & LPS & Reduces TNF- $\alpha$, IL-1, NO, and PGE2 & (Cheung et al., 2009) \\
\hline 26 & Augmentin & Mice & K. Pneumoniae & Decreases TNF- $\alpha$, NO, MPO, and MDA & (Bansal et al., 2010) \\
\hline 27 & Saikosaponin A & Male Sprague Dawley rats & $\mathrm{CCl}_{4}$ & $\begin{array}{l}\text { Decreases interferon- } \gamma \text {, TNF- } \alpha \text {, IL- } 1 \beta \text {, and IL- } 6 \text {, } \\
\text { by the inhibition of NF- } \kappa \beta \text { activation }\end{array}$ & (Wu et al., 2010) \\
\hline 28 & Essential turmeric oils & Male mice & DSS cholangitis & $\begin{array}{l}\text { Increases anti-inflammatory cytokines IL-10 } \\
\text { and IL-11 }\end{array}$ & (Toden et al., 2017) \\
\hline 29 & Erythromycin & Rat & Osteomyelitis model & $\begin{array}{l}\text { Reduces levels TNF- } \alpha \text { and IL- } 6 \text {, suppress bone } \\
\text { lesions, and decreases the histopathological score }\end{array}$ & (Zhou et al., 2017) \\
\hline 30 & Metformin & Male Wistar rat & Gentamicin & $\begin{array}{l}\text { Reduces MDA and NO and an increase in the } \\
\text { levels of SOD, CAT, GSH, and GPx }\end{array}$ & (Cao et al., 2019) \\
\hline 31 & Salsalate & Mice & High fat & Reduce IL- $1 \beta$ and IL-6 & (Wu et al., 2017) \\
\hline \multirow[t]{2}{*}{32} & Capsaicin & Male Wistar rats & Carrageenan & Reduces paw inflammation and 5-lipoxygenase & (Manjunatha et al., 2006) \\
\hline & & Male Wistar rats & Acetic acid & $\begin{array}{l}\text { Inhibition of vascular permeability and inhibition } \\
\text { of leukocyte mobilization }\end{array}$ & (Kumar et al., 2017) \\
\hline 33 & Selenium & Male albino Wistar & LPS & Reduces IL-6 & (Al-dossari et al., 2020) \\
\hline 34 & Irbesartan & Male albino rats & Streptozotocin & Reduces serum levels of IL- 6 and TNF- $\alpha$ & (Khaled et al., 2010) \\
\hline 35 & Acetylsalicylic acid & Wistar albino rats & Carrageenan & $\begin{array}{l}\text { Decreases in paw edema and MDA and increases } \\
\text { GSH and SOD }\end{array}$ & (Mohapatra et al., 2019) \\
\hline 36 & Hyaluronic acid & Male Wistar rat & CFA & $\begin{array}{l}\text { Reduce paw edema levels of the TNF- } \alpha \text {, IL- } 1 \text {, } \\
\text { and VEGF }\end{array}$ & (Fan et al., 2018) \\
\hline
\end{tabular}

The presence of oxidative stress causes chronic inflammation, which exerts a strong influence leading to modulation of the expression of the nucleus- $\kappa \beta(\mathrm{NF}-\kappa \beta)$ factor pathways and TNF- $\alpha$ pathways that amplify the infolammatory response (Reuter et al., 2010; Sethi et al., 2008). Curcumin inhibits constitutive $\mathrm{NF}-\kappa \beta$ and I $\kappa \mathrm{B}$ kinase (IKK). The suppression of proliferation, cell cycle arrest, and apoptosis induction caused by inhibition of several expression pathways of gene products are regulated by NF-к $\beta$ (Jobin et al., 1999; Shishodia et al., 2005).

\section{Enhancing the bioavailability of curcumin}

There have been many studies conducted to determine the bioavailability of oral curcumin using experimental rats' amount to around 1\% (Yang et al., 2007). Combinations of drugs can produce potent or reductive pharmacokinetic effects that may increase or decrease the therapeutic activity of one drug by the other drug through the regulation of absorption, distribution, metabolism, and excretion (Chou, 2006). Curcumin exhibits poor water solubility, chemical instability, and a low pharmacokinetic profile. Thus, the potential therapeutic activity provided by curcumin is debated because of the relatively poor bioavailability in humans regardless of its efficacy and safety (Dei Cas et al., 2019).

In this review, we found that the administration of piperine synergistically inhibits inflammation as compared to its single use. As a strong bioavailability enhancer, piperine can boost the bioavailability of curcumin (Jangra et al., 2016). Curcumin taken together with piperine in rats can increase the bioavailability of curcumin, as well as in humans, while it also leads to half-time elimination and significantly decreases the maximum time and clearance (Shoba et al., 1998). Curcumin absorption multiplies because piperine reduces the activity of the glucuronidase enzyme (Panahi et al., 2015). The additional mechanism of piperine enhances the bioavailability of curcumin by amplifying intestinal perfusion and enterocyte permeability (Atal et al., 1985; Shoba et al., 1998). Male Wistar rats treated with curcumin of $50 \mathrm{mg} / \mathrm{kg}$ and 
piperine of $2.5 \mathrm{mg} / \mathrm{kg}$ for 21 days orally reduced their inflammatory mediator parameters, such as NO, TNF- $\alpha$, and NF- $\kappa \beta$. Piperine has the activity of inhibiting glucuronidation of the small intestine, which causes increased absorption of curcumin. Piperine can also slow down the transit of curcumin in the digestive tract which results in increasing the remaining time in the intestine and allows for a higher absorption process (Bishnoi et al., 2011).

Curcumin is metabolized by intestinal microbiota, such as Escherichia coli and Blautia sp. These microbials are found to be active by an NADPH-dependent reductase in a two-step reduction pathway from curcumin to the intermediate product, dihydrocurcumin, and the end product, tetrahydrocurcumin (Hassaninasab et al., 2011). Similarly, a combination of piperine enables microbial metabolism in the digestive tract to convert curcumin into tetrahydrocurcumin. As a result, this metabolite can reach the adipose tissue (Neyrinck et al., 2013). Curcumin is reported to be a newly effective treatment for wound healing (Mohanty et al., 2017), since the addition of curcumin with emu oil may boost the flux by 1.84 and 4.25 times through the mouse skin, which can reduce the expression of proinflammatory mediators IL-1 $\beta$, IL-6, and TNF- $\alpha$ (Jeengar et al., 2016). In this review, increasing the bioavailability of curcumin can be done in combination with oral or topical use.

\section{Increasing antioxidant}

The structure of curcumin has many functional groups, including carbon-carbon double bonds; curcumin also contains $\beta$-diketone groups and phenyl rings containing hydroxyl and methoxy substituents. The presence of phenolic $\mathrm{OH}$ in the curcumin structure plays a major role in curcumin's activity (Priyadarsini et al., 2003; Wright, 2002). The combination of components may provide a synergistic effect, which will increase its efficacy at low doses to inhibit or eliminate tissue damage due to the initiation of oxidative stress. The combination of antioxidants can play a protective role in the development of oxidative stress and inflammation, by regulating key genes due to oxidative stress and also inhibiting the formation of cytokines that are responsible for inflammatory pathways (Vanella et al., 2017). Oxidative stimulation, proinflammatory cytokines, viruses, and LPS may activate NF- $\kappa \beta$, which eventually directs proteasomal degradation and phosphorylation of $\mathrm{IkB} \alpha$. This process will result in translocation that continues on the binding of NF- $\kappa \beta$ to the gene promoter region located in the nucleus so that it encodes the production of proinflammatory mediators, such as cytokines, COX-2, and iNOS (Wu et al., 2014).

Resveratrol and curcumin relieve and synergistically reverse tissue oxidative injury by increasing antioxidant defense through free radical scavenging. Resveratrol protects curcumin compounds by acting as an antioxidant that enables both substances to protect one another (Al Basher et al., 2020; Coradini et al., 2014). The ability of anti-inflammatory and antioxidant activity produced by curcumin at a dose of $50 \mathrm{mg} / \mathrm{kg}$ can be synergistically enhanced by combining it with quercetin of $50 \mathrm{mg} / \mathrm{kg}$ (Heeba et al., 2014). Administration of quercetin of $100 \mathrm{mg} / \mathrm{kg}$ and curcumin of $5 \mathrm{ml} / \mathrm{kg}$ should be carried out for 4 weeks. Diazinon-induced rats have a synergistic protective effect by reducing excessive MDA production, maintaining tissue antioxidant capacity, and improving liver enzymatic activity (Abdel-Diam et al., 2019).
The enhanced anti-inflammatory effect of the combination of berberine of $50 \mathrm{mg} / \mathrm{kg}$ and curcumin of $50 \mathrm{mg} / \mathrm{kg}$ may decrease oxidative stress, liver inflammation, and lipid metabolism (Feng et al., 2018). Berberine combination treatment also has a synergistic effect on reducing inflammatory and oxidative stress responses in the cortex and hippocampus of rats (Lin et al., 2020).

The addition of vitamins $\mathrm{E}$ increases the antioxidant capacity. Vitamin E $1.5 \mathrm{mg} / \mathrm{g}$ and $1 \mathrm{mg} / \mathrm{g}$ curcumin increases $\beta$ oxidation of fatty acids, increases CAT activity, and upregulates mitochondrial biogenesis. The combination decreases the percentage of hepatic steatosis and lobular inflammation (Heritage et al., 2017). The antioxidant effects decrease inflammation by vitamin B2 because it induces antioxidant genes like heme oxygenase 1 (HO-1), nuclear transcription factor erythroid 2 (Nrf2), and peroxisome proliferator-activated receptor-gamma coactivator-1 alpha (Vanella et al., 2017). The addition of curcumin to drugs, such as acetylsalicylic acid, Rhizoma Paridis saponins, and metformin, can prevent damage to the liver because curcumin is a strong antioxidant and increases SOD, GSH, HO-1, and CAT (Cao et al., 2019; Man et al., 2016; Mohapatra et al., 2019). The anti-inflammatory and antioxidant activity of curcumin can be synergistically enhanced by combining it with polyunsaturated fatty acid, docosahexaenoic acid, or eicosapentaenoic acid (Saw et $a l ., 2010)$. Patients with chronic gastritis who are given curcumin are treated with triple therapy regimes, which indicate antioxidant effects, inhibit oxidative damage to DNA cells, and ultimately reduce chronic inflammation rate (Judaki et al., 2017).

Many compounds are reported to have antioxidant capacities to directly scavenge ROS, to temper the mitochondrial respiratory chain and metal chelating agents, and to increase endogenous antioxidant enzymes, such as SOD, CAT, and glutathione peroxidase (Wolfe et al., 2008; Yahfoufi et al., 2018). An increase in antioxidant activity is due to certain mechanisms, such as the self-protecting mechanism because the combined compound is capable of simultaneously detecting multiple antioxidant functions and scavenging of some physiological radical species, inhibition of the prooxidant apoenzyme, and iron ion reducing and chelating activities (Soccio et al., 2018). These components act in a variety of antioxidant mechanisms enabling them to protect one another from oxidative agents (Becker et al., 2007). Differences in the orientation of the components at the water or lipid interface facilitate synergistic antioxidant interactions (Liang et al., 2009).

\section{Inhibiting inflammatory mediators, receptors, and major signaling pathways}

Chemical constituents have interactions on inflammatory marker cells and signaling pathways for which these interactions are very specific. The critical point of the combined delivery method is to reach the threshold level of pathway activation, while the individual components cannot reach this level (Zhang, et al., 2019). Resveratrol (Dull et al., 2019), quercetin (Li et al., 2016), puerarin (Wei et al., 2014), luteolin (Aziz et al., 2018), and thymoquinone (Shaterzadeh-Yazdi et al., 2018) are reported to inhibit proinflammatory molecules, such as TNF- $\alpha$, IL- $1 \beta$, IL-6, and NO. Quercetin (Lee et al., 2008) and resveratrol (Yu et al., 2018) inhibit enzymes that trigger increased inflammation, such as COX-2 and iNOS, on RAW 264.7 cells which are 
also able to reduce the amount of NO by regulating the NF- $\kappa \beta$ pathway. Phytochemical compounds, such as resveratrol, and a class of flavonoids, such as luteolin and quercetin, are known to have the activity of stimulating the expression of the antiinflammatory cytokine IL-10 (Comalada et al., 2006; Imler et al., 2009). Flavocoxid shows a significant anti-inflammatory activity inhibition of the MDA, TNF $\alpha$, nitrite levels, COX-1, and COX-2 (Altavilla et al., 2009; Bitto et al., 2014). The combined effect of vitamin D and curcumin fights inflammation by reducing T-cell activation and proliferation, thereby preventing altered lymphocyte activity in rheumatic rats (da Silva et al., 2019). The combination of curcumin with these components has cell-specific interactions, signaling pathways, and inflammatory markers. Two or more components can focus on the same immune cell or different cells, regulating the production of inflammatory markers along the same or different pathways to cause a synergistic antiinflammatory effect.

Chronic inflammation that leads to carcinogenesis involves the occurrence of molecular events, including upregulation of enzymes that promote inflammation, such as cytokines, and activation of immune cells. mammalian target of rapamycin complex 1 (mTORC1) dysregulation initiates the pathology of human diseases, one of which is cancer. The combination of curcumin and piperine is able to regulate $\mathrm{mTORC} 1$ activity that is stronger than the use of curcumin alone. In this combination, piperine acts via mTORC1 to suppress the TNF- $\alpha$ signaling pathway and COX-2 expression (Kaur et al., 2018). The ability of curcumin and piperine to suppress the NF- $\kappa \beta$ signaling pathway can trigger inflammation; this inhibition blocks the production of TNF- $\alpha$ and reduces the expression of intercellular protein, adhesion molecule-1, and vascular cell adhesion molecule-1 (VCAM-1) (Karimian et al., 2017; Kumar et al., 2007).

The main inflammatory mediators, such as TNF- $\alpha$, without proper control and chronic secretion of TNF- $\alpha$ cause intermediates for various chronic inflammatory diseases, autoimmune or more severe cancer (Aggarwal et al., 2006). The addition of luteolin synergistically inhibits TNF- $\alpha$-induced monocyte adhesion and MCP-1 and VCAM-1 expression by suppressing translocation of NF- $\kappa \beta$ into the nucleus (Zhang, et al., 2019). The combined synergistic effect of curcumin and resveratrol gives a CI value of $\mathrm{CI}<1.0$ on inhibition of colon cancer growth, which is associated with inhibition of proliferation and stimulation of apoptosis, accompanied by weakened NF- $\kappa \beta$ activity (Majumdar et al., 2009). Curcumin and capsaicin have been shown to attenuate the activation of $\mathrm{NF}-\kappa \beta$; the inhibitory effect of inflammation of both components occurs in the enzyme 5-lipoxygenase in animals injected with carrageenan (Manjunatha et al., 2006). Mixed curcuminoid extract, hydrolyzed collagen, and green tea extract can reduce inflammation and reduce the inflammatory synthesis and catabolic mediators by chondrocytes, by way of inhibiting the activation of NF- $\kappa \beta$ (Comblain et al., 2015). Both resveratrol and curcumin have activity in suppressing the NF- $\kappa \beta$ signal transduction pathway with the ability of resveratrol to retain phosphorylated $\mathrm{I} \kappa \mathrm{B} \alpha$ and inhibit translocation of activated NF- $\kappa \beta$ to the nucleus. The activity of lowering the translocation of activated NF- $\kappa \beta$ to the nucleus is also exerted by curcumin (Csaki et al., 2009).
The inflammatory process involves cytokines which are the main signaling proteins in response to inflammation. Their immune system is divided into proinflammatory cytokines IL1, IL-6, IL-15, IL-17, IL-23, and TNF- $\alpha$ and anti-inflammatory cytokines IL-4, IL-10, and IL-13, thereby altering growth factor $\beta$ and interferon $\gamma$ (Berczi et al., 2003). Interleukins are a major class of cytokines that play an important role in immune modulation. This modulation includes IL-1 which regulates the transformation of phagocytes that infiltrate during inflammation or cancer which triggers the production of free radicals, such as ROS and reactive nitrogen species, and the formation of inflammatory molecules, such as chemokines, integrins, and MMP (Apte et al., 2006). Curcumin of $1 \mathrm{gr} / \mathrm{kg}$ and piperine of $50 \mathrm{mg} / \mathrm{kg}$ can reduce the weight of mice induced by high fat and significantly reduce IL-1 $\beta$ (Miyazawa et al., 2018). In acute inflammation, the presence of IL-6 plays an important role, if uncontrolled production causes various types of inflammatory diseases (Balkwill et al., 2010). The combination of curcumin and ursolic acid has a significant effect on inhibiting the phosphorylation of $\mathrm{I} \kappa \mathrm{B} \alpha$ and $\mathrm{NF}-\kappa \beta$. Inhibition of the NF- $\kappa \beta$ signaling pathway is due to decreased COX-2 protein levels and reduced expression of inflammatory marker genes, such as IL-1 $\beta$, IL-6, and CXCL2 (Tremmel et al., 2019). Puerarin with curcumin suppresses the proinflammatory cytokines IL$1 \beta$ and MMP-9 and increases anti-inflammatory cytokines, such as IL-10 in LPS-induced Sprague Dawley rats so that it is more effective and nontoxic (Singh et al., 2013). Administration of LPS causes a change in behavior and an increase in cytokine levels in mice, while administration of $5 \mathrm{mg} / \mathrm{kg}$ salidroside and $20 \mathrm{mg} /$ $\mathrm{kg}$ of curcumin shows antidepressant-like effects comparable to fluoxetine and potential synergistic reduction of IL- 6 and TNF- $\alpha$ and anti-stress effects (Vasileva et al., 2018).

The action of anti-inflammatory combination regulates multiple pathways, blocks the MAPK pathway, and activates NF$\kappa \beta$ induced by cytokines and proinflammatory gene expression by inhibiting the activity of the inhibiting I-kB kinase. It also inhibits prostaglandin production by blocking arachidonic acid pathways and iNOS expression and blocking the proinflammatory cytokine synthesis pathway, which in turn suppresses the proliferation and reduces the production of proinflammatory markers and migration of immune cells and ultimately inhibits inflammation

\section{CONCLUSION}

The anti-inflammatory effect of the curcumin combination results from increased antioxidant, increased bioavailability of curcumin, regulation of multiple pathways, and inflammatory markers. The combination with some components can directly scavenge intensified ROS and increase antioxidants to reduce the effects of oxidative stress. The reduced ROS directly regulates further attenuation of the $\mathrm{NF}-\kappa \beta$ signaling pathway. Attenuated $\mathrm{NF}-\kappa \beta$ deregulates transcription and translation processes in proinflammatory markers, and increases antiinflammatory molecules. The bioavailability of curcumin can be increased by combining it with piperine. This review provides clues to encourage more researches on combined compounds as a way to reduce inflammation. The current review has provided an overview of how the molecular mechanisms of inflammation occur and their pharmacological treatments and also the way 
curcumin compounds may interact in their pharmacological effects while avoiding adverse side effects. The development of drug combination strategies is essential for better treatment of a variety of acute and chronic inflammatory conditions. In this review, we collected and analyzed research data on the curcumin combination and concluded that there are several components to be combined with curcumin as a way to incur anti-inflammatory activity, and such experiments have been in clinical trials.

\section{ACKNOWLEDGMENT}

The authors would like to acknowledge the funding support from UGM no. 2488/UN1.PIII/DIT-LIT/PT/2020.

\section{AUTHOR CONTRIBUTION}

Putu Yudhistira Budhi Setiawan contributed to the conception and design in this study, as well as collecting and analyzing data. Subagus Wahyuono, Nyoman Kertia, and Arief Nurrochmand contributed to critical revisions and supervision.

\section{CONFLICT OF INTEREST}

The authors declare that there is no conflict of interest.

\section{ETHICAL APPROVALS}

Not applicable.

\section{PUBLISHER'S NOTE}

This journal remains neutral with regard to jurisdictional claims in published institutional affiliation.

\section{REFERENCES}

Abdel-Daim MM, Abdou RH. Protective effects of diallyl sulfide and curcumin separately against thallium-induced toxicity in rats. Cell J, 2015; 17(2):379-88.

Abdel-Diam MM, Samak DH, El-Sayed YS, Aleya L, Alarifi S, Alkahtani S. Curcumin and quercetin synergistically attenuate subacute diazinon-induced inflammation and oxidative neurohepatic damage, and acetylcholinesterase inhibition in albino rats. Environ Sci Pollut Res Int, 2019; 26(4):3659-65.

Abdel-Magied N, Elkady AA. Possible curative role of curcumin and silymarin against nephrotoxicity induced by gamma-rays in rats. Exp Mol Pathol, 2019; 111(104299):1-9.

Aggarwal BB, Gupta SC, Sung B. Curcumin: an orally bioavailable blocker of TNF and other pro-inflammatory biomarkers. Br J Pharmacol, 2013; 169(8):1672-92.

Aggarwal BB, Shishodia S, Sandur SK, Pandey MK, Sethi G. Inflammation and cancer: how hot is the link? Biochem Pharmacol, 2006; 72(11):1605-21.

Ahsan H, Parveen N, Khan NU, Hadi SM. Pro-oxidant, antioxidant and cleavage activities on DNA of curcumin and its derivatives demethoxycurcumin and bisdemethoxycurcumin. Chem Biol Interact, 1999; 121(2):161-75.

Al Basher G, Abdel-Daim MM, Almeer R, Ibrahim KA, Hamza RZ, Bungau S, Aleya L. Synergistic antioxidant effects of resveratrol and curcumin against fipronil-triggered oxidative damage in male albino rats. Environ Sci Pollut Res Int, 2020; 27(6):6505-14.

Al Fayi M, Otifi H, Alshyarba M, Dera AA, Rajagopalan P. Thymoquinone and curcumin combination protects cisplatin-induced kidney injury, nephrotoxicity by attenuating NFאB, KIM-1 and ameliorating Nrf2/HO-1 signalling. J Drug Target, 2020; 28(9):913-22.

Al-dossari MH, Fadda LM, Attia HA, Hasan IH, Mahmoud AM. Curcumin and selenium prevent lipopolysaccharide/diclofenac-induced liver injury by suppressing inflammation and oxidative stress. Biol Trace Elem Res, 2020; 196(1):173-83.

Altavilla D, Squadrito F, Bitto A, Polito F, Burnett BP, Stefano VD, Minutoli L. Flavocoxid, a dual inhibitor of cyclooxygenase and 5-lipoxygenase, blunts pro-inflammatory phenotype activation in endotoxin-stimulated macrophages. Br J Pharmacol, 2009; 157(8):1410-8.

Ammon HP, Safayhi H, Mack T, Sabieraj J. Mechanism of antiinflammatory actions of curcumine and boswellic acids. J Ethnopharmacol, 1993; 38(2-3):113-9.

Anthwal A, Thakur BK, Rawat MSM, Rawat DS, Tyagi AK, Aggarwal BB. Synthesis, characterization and in vitro anticancer activity of $\mathrm{C}-5$ curcumin analogues with potential to inhibit TNF- $\alpha$-induced NF- $\kappa \beta$ activation. Biomed Res Int, 2014; 2014(524161):1-10.

Apte RN, Krelin Y, Song X, Dotan S, Recih E, Elkabets M, Carmi Y, Dvorkin T, White RM, Gayvoronsky L, Segal S, Voronov E. Effects of micro-environment- and malignant cell-derived interleukin-1 in carcinogenesis, tumour invasiveness and tumour-host interactions. Eur J Cancer, 2006; 42(6):751-9.

Atal CK, Dubey RK, Singh J. Biochemical basis of enhanced drug bioavailability by piperine: evidence that piperine is a potent inhibitor of drug metabolism. J Pharmacol Exp Ther, 1985; 232(1):258-62.

Aziz N, Kim M-Y, Cho JY. Anti-inflammatory effects of luteolin: a review of in vitro, in vivo, and in silico studies. J Ethnopharmacol, 2018; 225:342-58.

Bacchi S, Palumbo P, Sponta A, Coppolino MF. Clinical pharmacology of non-steroidal anti-inflammatory drugs: a review. Antiinflamm Antiallergy Agents Med Chem, 2012; 11(1):52-64.

Balkwill F, Mantovani A. Cancer and inflammation: implications for pharmacology and therapeutics. Clin Pharmacol Ther, 2010; 87(4): $401-6$.

Bansal S, Chhibber S. Curcumin alone and in combination with augmentin protects against pulmonary inflammation and acute lung injury generated during Klebsiella pneumoniae B5055-induced lung infection in BALB/c mice. J Med Microbiol, 2010; 59(4):429-37.

Becker EM, Ntouma G, Skibsted LH. Synergism and antagonism between quercetin and other chain-breaking antioxidants in lipid systems of increasing structural organisation. Food Chem, 2007; 103(4):1288-96.

Ben-Baruch A. Inflammation-associated immune suppression in cancer: the roles played by cytokines, chemokines and additional mediators. Semin Cancer Biol, 2006; 16(1):38-52.

Berczi I, Szentivanyi A. Cytokines and chemokines: the immuneneuroendocrine circuitry history and progress. In: Berczi I, Szentivanyi A (eds.). NeuroImmune biology. Elsevier, Amsterdam, Netherlands, pp 191220, 2003.

Bishnoi M, Chopra K, Rongzhu L, Kulkarni SK. Protective effect of curcumin and its combination with piperine (bioavailability enhancer) against haloperidol-associated neurotoxicity: cellular and neurochemical evidence. Neurotox Res, 2011; 20(3):215-25.

Bitto A, Squadrito F, Irrera N, Pizzino G, Pallio G, Mecchio A, Galfo F, Altavilla D. Flavocoxid, a nutraceutical approach to blunt inflammatory conditions. Mediators Inflamm, 2014; 2014(790851):1-8.

Buchman AL. Side effects of corticosteroid therapy. J Clin Gastroenterol, 2001; 33(4):289-94.

Bulusu KC, Guha R, Mason DJ, Lewis RPI, Muratov E, Motamedi YK, Cokol M, Bender A. Modelling of compound combination effects and applications to efficacy and toxicity: state-of-the-art, challenges and perspectives. Drug Discov Today, 2016; 21(2):225-38.

Cao L, Zhi D, Han J, Kumar Sah S, Xie Y. Combinational effect of curcumin and metformin against gentamicin-induced nephrotoxicity: involvement of antioxidative, anti-inflammatory and antiapoptotic pathway. J Food Biochem, 2019; 43(7):e12836.

Chan MM, Huang HI, Fenton MR, Fong D. In vivo inhibition of nitric oxide synthase gene expression by curcumin, a cancer preventive natural product with anti-inflammatory properties. Biochem Pharmacol, 1998; 55(12):1955-62. 
Chen L, Deng H, Cui H, Fang J, Zuo Z, Deng J, Li Y, Wang X, Zhao L. Inflammatory responses and inflammation-associated diseases in organs. Oncotarget, 2018; 9(6):7204-18.

Cheung KL, Khor TO, Kong AN. Synergistic effect of combination of phenethyl isothiocyanate and sulforaphane or curcumin and sulforaphane in the inhibition of inflammation. Pharm Res, 2009; 26(1):224-31.

Cho JW, Lee KS, Kim CW. Curcumin attenuates the expression of IL-1beta, IL-6, and TNF-alpha as well as cyclin E in TNF-alpha-treated HaCaT cells; NF-kappaB and MAPKs as potential upstream targets. Int J Mol Med, 2007; 19(3):469-74.

Chou TC. Drug combination studies and their synergy quantification using the Chou-Talalay method. Cancer Res, 2010; 70(2):440-6.

Chou TC. Theoretical basis, experimental design, and computerized simulation of synergism and antagonism in drug combination studies. Pharmacol Rev, 2006; 58(3):621-81.

Chung SH, Choi SH, Choi JA, Chuck RS, Joo CK. Curcumin suppresses ovalbumin-induced allergic conjunctivitis. Mol Vis, 2012; 18:1966-72.

Comalada M, Ballester I, Bailón E, Sierra S, Xaus J, Gálvez J, de Medina FS, Zarzuelo A. Inhibition of pro-inflammatory markers in primary bone marrow-derived mouse macrophages by naturally occurring flavonoids: analysis of the structure-activity relationship. Biochem Pharmacol, 2006; 72(8):1010-21.

Comblain F, Sanchez C, Lesponne I, Balligand M, Serisier S, Henrotin Y. Curcuminoids extract, hydrolyzed collagen and green tea extract synergically inhibit inflammatory and catabolic mediator's synthesis by normal bovine and osteoarthritic human chondrocytes in monolayer. PLoS One, 2015; 10(3):1-20.

Coradini K, Friedrich RB, Fonseca FN, Vencato MS, Andrade DF, Oliveira CM, Battistel AP, Guterres SS, da Rocha MIUM, Pohlmann AR, Beck RCR. A novel approach to arthritis treatment based on resveratrol and curcumin co-encapsulated in lipid-core nanocapsules: in vivo studies. Eur J Pharm Sci, 2015; 78:163-70.

Coradini K, Lima FO, Oliveira CM, Chaves PS, Athayde ML, Carvalho LM, Beck RCR. Co-encapsulation of resveratrol and curcumin in lipid-core nanocapsules improves their in vitro antioxidant effects. Eur J Pharm Biopharm, 2014; 88(1):178-85.

Corrêa MG, Pires PR, Ribeiro FV, Pimentel SZ, Casarin RCV, Cirano FR, Tenenbaum HT, Casati MZ. Systemic treatment with resveratrol and/or curcumin reduces the progression of experimental periodontitis in rats. J Periodontal Res, 2017; 52(2):201-9.

Csaki C, Mobasheri A, Shakibaei M. Synergistic chondroprotective effects of curcumin and resveratrol in human articular chondrocytes: inhibition of IL-1beta-induced NF-kappaB-mediated inflammation and apoptosis. Arthritis Res Ther, 2009; 11(6):1-17.

D'Ascola A, Irrera N, Ettari R, Bitto A, Pallio G, Mannino F, Atteritano M, Campo GM, Minutoli L, Arcoraci V, Squadrito V, Picciolo G, Squadrito F, Altavilla D. Exploiting curcumin synergy with natural products using quantitative analysis of dose-effect relationships in an experimental in vitro model of osteoarthritis. Front Pharmacol, 2019; 10(1347):1-9

da Silva JLG, Passos DF, Bernardes VM, Cabral FL, Schimites PG, Manzoni AG, de Oliveira EG, de Bona da Silva C, Beck RCR, Jantsch MH, Maciel RM, Leal DBR. Co-nanoencapsulation of vitamin D3 and curcumin regulates inflammation and purine metabolism in a model of arthritis. Inflammation, 2019; 42(5):1595-610.

Dai C, Tang S, Li D, Zhao K, Xiao X. Curcumin attenuates quinocetone-induced oxidative stress and genotoxicity in human hepatocyte L02 cells. Toxicol Mech Methods, 2015; 25(4):340-6.

Dei Cas M, Ghidoni R. Dietary curcumin: correlation between bioavailability and health potential. Nutrients, 2019; 11(9):1-14.

Dull AM, Moga MA, Dimienescu OG, Sechel G, Burtea V, Anastasiu CV. Therapeutic approaches of resveratrol on endometriosis via anti-inflammatory and anti-angiogenic pathways. Molecules [En ligne], 2019;24(4):1-21.

Fan Z, Li J, Liu J, Jiao H, Liu B. Anti-inflammation and joint lubrication dual effects of a novel hyaluronic acid/curcumin nanomicelle improve the efficacy of rheumatoid arthritis therapy. ACS Appl Mater Interfaces, 2018; 10(28):23595-604.

Feng WW, Kuang SY, Tu C, Ma ZJ, Pang JY, Wang YH, Zang QC, Liu TS, Zhao YL, Xiao XH, Wang JB. Natural products berberine and curcumin exhibited better ameliorative effects on rats with non-alcohol fatty liver disease than lovastatin. Biomed Pharmacother, 2018; 99:325-33.

Fu XY, Yang MF, Cao MZ, Li DW, Yang XY, Sun JY, Zhang ZY, Mao LL, Zhang S, Wang FZ, Zhang F, Fan CD, Sun BL. Strategy to suppress oxidative damage-induced neurotoxicity in PC12 cells by curcumin: the role of ROS-mediated DNA damage and the MAPK and AKT pathways Mol Neurobiol, 2016; 53(1):369-78.

Gan Z, Wei W, Li Y, Wu J, Zhao Y, Zhang L, Wang T, Zhong X. Curcumin and resveratrol regulate intestinal bacteria and alleviate intestinal inflammation in weaned piglets. Molecules, 2019; 24(7):1-14.

Gheibi S, Gouvarchin Ghaleh HE, Motlagh BM, Azarbayjani AF, Zarei L. Therapeutic effects of curcumin and ursodexycholic acid on nonalcoholic fatty liver disease. Biomed Pharmacother, 2019; 115(108938):1-8.

Goel A, Boland CR, Chauhan DP. Specific inhibition of cyclooxygenase-2 (COX-2) expression by dietary curcumin in HT-29 human colon cancer cells. Cancer Lett, 2001; 172(2):111-8.

Gulcubuk A, Haktanir D, Cakiris A, Ustek D, Guzel O, Erturk M, Karabagli M, Akyazi I, Cicekci H, Altunatmaz K, Uzun H, Ates K. Effects of curcumin on proinflammatory cytokines and tissue injury in the early and late phases of experimental acute pancreatitis. Pancreatology, 2013; 13(4):347-54.

Gupta SC, Tyagi AK, Deshmukh-Taskar P, Hinojosa M, Prasad $\mathrm{S}$, Aggarwal BB. Downregulation of tumor necrosis factor and other proinflammatory biomarkers by polyphenols. Arch Biochem Biophys, 2014; 559:91-9.

Güran M, Şanlıtürk G, Kerküklü NR, Altundağ EM, Süha Yalçın A. Combined effects of quercetin and curcumin on anti-inflammatory and antimicrobial parameters in vitro. Eur J Pharmacol, 2019; 859(172486):1-9.

Hassaninasab A, Hashimoto Y, Tomita-Yokotani K, Kobayashi M. Discovery of the curcumin metabolic pathway involving a unique enzyme in an intestinal microorganism. Proc Natl Acad Sci U S A, 2011; 108(16):6615-20.

Hatcher H, Planalp R, Cho J, Torti FM, Torti SV. Curcumin: from ancient medicine to current clinical trials. Cell Mol Life Sci, 2008; 65(11):1631-52.

Heeba GH, Mahmoud ME, El Hanafy AA. Anti-inflammatory potential of curcumin and quercetin in rats: role of oxidative stress, heme oxygenase-1 and TNF- $\alpha$. Toxicol Ind Health, 2014; 30(6):551-60.

Heritage M, Jaskowski L, Bridle K, Campbell C, Briskey D, Britton L, Fletcher L, Vitetta L, Subramaniam VN, Crawford D. Combination curcumin and vitamin $\mathrm{E}$ treatment attenuates diet-induced steatosis in Hfe/- mice. World J Gastrointest Pathophysiol, 2017; 8(2):67-76.

Hong J, Bose M, Ju J, Ryu JH, Chen X, Sang S, Lee MJ, Yang CS. Modulation of arachidonic acid metabolism by curcumin and related beta-diketone derivatives: effects on cytosolic phospholipase A(2), cyclooxygenases and 5-lipoxygenase. Carcinogenesis, 2004; 25(9):1671-9.

Imler TJ, Petro TM. Decreased severity of experimental autoimmune encephalomyelitis during resveratrol administration is associated with increased IL-17+IL-10+ T cells, CD4- IFN- $\gamma+$ cells, and decreased macrophage IL-6 expression. Int Immunopharmacol, 2009; 9(1):134-43.

Jain SK, Rains J, Croad J, Larson B, Jones K. Curcumin supplementation lowers TNF-alpha, IL-6, IL-8, and MCP-1 secretion in high glucose-treated cultured monocytes and blood levels of TNF-alpha, IL6 , MCP-1, glucose, and glycosylated hemoglobin in diabetic rats. Antioxid Redox Signal, 2009; 11(2):241-9. 
Jangra A, Kwatra M, Singh T, Pant R, Kushwah P, Sharma $\mathrm{Y}$, et al. Piperine augments the protective effect of curcumin against lipopolysaccharide-induced neurobehavioral and neurochemical deficits in mice. Inflammation, 2016; 39(3):1025-38.

Jeengar MK, Shrivastava S, Mouli Veeravalli SC, Naidu VGM, Sistla R. Amelioration of FCA induced arthritis on topical application of curcumin in combination with emu oil. Nutrition, 2016; 32(9):955-64.

Jeengar MK, Shrivastava S, Nair K, Singareddy SR, Putcha UK, Talluri MVNK, Naidu VGM, Sistla R. Improvement of bioavailability and anti-inflammatory potential of curcumin in combination with emu oil. Inflammation, 2014; 37(6):2139-55.

Jia Q, Ivanov I, Zlatev ZZ, Alaniz RC, Weeks BR, Callaway ES, Goldsby JS, Davidson LA, Fan YY, Zhou L, Lupton JR, McMurray DN, Chapkin RS. Dietary fish oil and curcumin combine to modulate colonic cytokinetics and gene expression in dextran sodium sulphate-treated mice. Br J Nutr, 2011; 106(4):519-29.

Jin CY, Lee JD, Park C, Choi YH, Kim GY. Curcumin attenuates the release of pro-inflammatory cytokines in lipopolysaccharide-stimulated BV2 microglia. Acta Pharmacol Sin, 2007; 28(10):1645-51.

Jobin C, Bradham CA, Russo MP, Juma B, Narula AS, Brenner DA, Sartor RB. Curcumin blocks cytokine-mediated NF-kappa B activation and proinflammatory gene expression by inhibiting inhibitory factor I-kappa B kinase activity. J Immunol, 1999; 163(6):3474-83.

Judaki A, Rahmani A, Feizi J, Asadollahi K, Hafezi Ahmadi MR. Curcumin in combination with triple therapy regimes ameliorates oxidative stress and histopathologic changes in chronic gastritis-associated helicobacter pylori infection. Arq Gastroenterol, 2017; 54(3):177-82.

Karimian MS, Pirro M, Johnston TP, Majeed M, Sahebkar A. Curcumin and endothelial function: evidence and mechanisms of protective effects. Curr Pharm Des, 2017; 23(17):2462-73.

Kaur H, He B, Zhang C, Rodriguez E, Hage DS, Moreau R. Piperine potentiates curcumin-mediated repression of mTORC1 signaling in human intestinal epithelial cells: implications for the inhibition of protein synthesis and TNF $\alpha$ signaling. J Nutr Biochem, 2018; 57:276-86.

Khaled M, Mahfouz M. Curcumin/irbesartan combination improves insulin sensitivity and ameliorates serum pro-inflammatory cytokines levels in diabetes rat model. J Am Sci, 2010; 6(11):1051-9.

Khayyal MT, El-Hazek RM, El-Sabbagh WA, Frank J, Behnam D, Abdel-Tawab M. Micellar solubilisation enhances the antiinflammatory activities of curcumin and boswellic acids in rats with adjuvant-induced arthritis. Nutrition, 2018; 54:189-96.

Kobayashi T, Hashimoto S, Horie T. Curcumin inhibition of Dermatophagoides farinea-induced interleukin-5 (IL-5) and granulocyte macrophage-colony stimulating factor (GM-CSF) production by lymphocytes from bronchial asthmatics. Biochem Pharmacol, 1997; 54(7):819-24

Kumar S, Singhal V, Roshan R, Sharma A, Rembhotkar GW, Ghosh B. Piperine inhibits TNF-alpha induced adhesion of neutrophils to endothelial monolayer through suppression of NF-kappaB and IkappaB kinase activation. Eur J Pharmacol, 2007; 575(1-3):177-86.

Kumar TV, Manjunatha H, Rajesh KP. Anti-inflammatory activity of curcumin and Capsaicin augmented in combination. Int J Pharm Pharm Sci, 2017; 9(6):145-9.

Kunnumakkara AB, Diagaradjane P, Anand P, Harikumar KB, Kuzhuvelil HB, Deorukhkar A, Deorukhkar A, Gelovani J, Guha S, Krishnan S, Aggarwal BB. Curcumin sensitizes human colorectal cancer to capecitabine by modulation of cyclin D1, COX-2, MMP-9, VEGF and CXCR4 expression in an orthotopic mouse model. Int J Cancer, 2009; 125(9):2187-97.

Lawrence T. The nuclear factor NF-B pathway in inflammation. Cold Spring Harb Perspect Biol, 2009; 1(6):1-10

Lee S, Park HS, Notsu Y, Ban HS, Kim YP, Ishihara K, Hirasawa N, Jung SH, Lee YS, Lim SS, Park EH, Shin KH, Seyama T, Hong J, Ohuchi $\mathrm{K}$. Effects of hyperin, isoquercitrin and quercetin on lipopolysaccharide- induced nitrite production in rat peritoneal macrophages. Phytother Res, 2008; 22(11):1552-6.

Lestari MLAD, Indrayanto G. Chapter three: curcumin In: Brittain HG (ed.). Profiles drug substances excipients and related methodology, Elsevier, Milford, NJ, pp 113-204, 2014.

Li Y, Yao J, Han C, Yang J, Chaudhry MT, Wang S, Liu H, Yin Y. Quercetin, inflammation and immunity. Nutrients, 2016; 8(3):1-14.

Liang R, Han RM, Fu LM, Ai XC, Zhang JP, Skibsted LH. Baicalin in radical scavenging and its synergistic effect with beta-carotene in antilipoxidation. J Agric Food Chem, 2009; 57(15):7118-24.

Lijuan Z, Wang X, L Zhang, Virgous C, Si H. Combination of curcumin and luteolin synergistically inhibits TNF- $\alpha$-induced vascular inflammation in human vascular cells and mice. J Nutr Biochem, 2019; 73(108222):1-8.

Lin L, Li C, Zhang D, Yuan M, Chen CH, Li M. Synergic effects of berberine and curcumin on improving cognitive function in an Alzheimer's disease mouse model. Neurochem Res, 2020; 45(5):1130-41.

Majumdar APN, Banerjee S, Nautiyal J, Patel BB, Patel V, Du J, Du J, Yu Y, Elliott AA, Levi E, Sarkar FH. Curcumin synergizes with resveratrol to inhibit colon cancer. Nutr Cancer, 2009; 61(4):544-53.

Malhotra A, Nair P, Dhawan DK. Curcumin and resveratrol synergistically stimulate $\mathrm{p} 21$ and regulate cox- 2 by maintaining adequate zinc levels during lung carcinogenesis. Eur J Cancer Prev, 2011; 20(5):4116.

Man S, Li J, Liu J, Chai H, Liu Z, Wang J, Gao W. Curcumin alleviated the toxic reaction of rhizoma paridis saponins in a 45-day subchronic toxicological assessment of rats. Environ Toxicol, 2016; 31(12):1935-43.

Manjunatha H, Srinivasan K. Protective effect of dietary curcumin and capsaicin on induced oxidation of low-density lipoprotein, iron-induced hepatotoxicity and carrageenan-induced inflammation in experimental rats. FEBS J, 2006; 273(19):4528-37.

Martins CA, Leyhausen G, Volk J, Geurtsen W. Curcumin in combination with piperine suppresses osteoclastogenesis in vitro. J Endod, 2015; 41(10):1638-45.

Meshkibaf M, Maleknia M, Noroozi S. Effect of curcumin on gene expression and protein level of methionine sulfoxide reductase A (MSRA), SOD, CAT and GPx in Freund's adjuvant inflammation-induced male rats. J Inflamm Res, 2019; 12:241-9.

Miyazawa Taiki, Nakagawa K, Kim SH, Thomas MJ, Paul L, Zingg J-M, Dolnikowski GG, Roberts SB, Kimura F, Miyazawa T, Azzi A, Meydani M. Curcumin and piperine supplementation of obese mice under caloric restriction modulates body fat and interleukin- $1 \beta$. Nutr Metab (Lond), 2018; 15(12):1-9.

Mohanty C, Sahoo SK. Curcumin and its topical formulations for wound healing applications. Drug Discov Today, 2017; 22(10):1582-92.

Mohapatra TK, Nayak RR, Subudhi BB. Curcumin enhances effects of acetylsalicylic acid. J Pharm Pharmacognosy Res, 2019; 7(5):310-22.

Moon D-O, Kim M-O, Choi YH, Park Y-M, Kim G-Y Curcumin attenuates inflammatory response in IL-1beta-induced human synovial fibroblasts and collagen-induced arthritis in mouse model. Int Immunopharmacol, 2010; 10(5):605-10.

Murakami A, Furukawa I, Miyamoto S, Tanaka T, Ohigashi H. Curcumin combined with turmerones, essential oil components of turmeric, abolishes inflammation-associated mouse colon carcinogenesis. Biofactors, 2013; 39(2):221-32.

Neyrinck AM, Alligier M, Memvanga PB, Névraumont E, Larondelle Y, Préat V, Cani PD, Delzenne NM. Curcuma longa extract associated with white pepper lessens high fat diet-induced inflammation in subcutaneous adipose tissue. PLoS One, 2013; 8(11):1-10.

Nilani P, Kasthuribai N, Duraisamy B, Dhamodaran P, Ravichandran S, Ilango K, Suresh B. In vitro antioxidant activity of selected antiasthmatic herbal constituents. Anc Sci Life, 2009; 28(4):3-6. 
Noorafshan A, Esfahani S. A review of therapeutic effects of curcumin. Curr Pharm Des, 2013; 19:2032-46.

Oray M, Abu Samra K, Ebrahimiadib N, Meese H, Foster CS. Long-term side effects of glucocorticoids. Expert Opin Drug Saf, 2016; 15(4):457-65.

Panahi Y, Hosseini MS, Khalili N, Naimi E, Majeed M, Sahebkar A. Antioxidant and anti-inflammatory effects of curcuminoid-piperine combination in subjects with metabolic syndrome: a randomized controlled trial and an updated meta-analysis. Clin Nutr, 2015; 34(6):1101-8.

Priyadarsini KI, Maity DK, Naik GH, Kumar MS, Unnikrishnan MK, Satav JG, Mohan H. Role of phenolic O-H and methylene hydrogen on the free radical reactions and antioxidant activity of curcumin. Free Radic Biol Med, 2003; 35(5):475-84.

Pulido-Moran M, Moreno-Fernandez J, Ramirez-Tortosa C, Ramirez-Tortosa M. Curcumin and Health. Molecules, 2016; 21(3):1-22

Ramsewak RS, DeWitt DL, Nair MG. Cytotoxicity, antioxidant and anti-inflammatory activities of curcumins I-III from Curcuma longa. Phytomedicine, 2000; 7(4):303-8.

Reddy AC, Lokesh BR. Studies on spice principles as antioxidants in the inhibition of lipid peroxidation of rat liver microsomes. Mol Cell Biochem, 1992; 111(1-2):117-24.

Reuter S, Gupta SC, Chaturvedi MM, Aggarwal BB. Oxidative stress, inflammation, and cancer: how are they linked? Free Radic Biol Med, 2010; 49(11):1603-16.

Rinwa P, Kumar A, Garg S. Suppression of neuroinflammatory and apoptotic signaling cascade by curcumin alone and in combination with piperine in rat model of olfactory bulbectomy induced depression. PLoS One, 2013; 8(4):1-11.

Saw CLL, Huang Y, Kong AN. Synergistic anti-inflammatory effects of low doses of curcumin in combination with polyunsaturated fatty acids: docosahexaenoic acid or eicosapentaenoic acid. Biochem Pharmacol, 2010; 79(3):421-30.

Sethi G, Sung B, Aggarwal BB. Nuclear factor-kappaB activation: from bench to bedside. Exp Biol Med (Maywood), 2008; 233(1):21-31.

Shaterzadeh-Yazdi H, Noorbakhsh MF, Hayati F, Samarghandian $\mathrm{S}$, Farkhondeh T. Immunomodulatory and anti-inflammatory effects of thymoquinone. Cardiovasc Hematol Disord Drug Targets, 2018; 18(1): $52-60$.

Shishodia S, Amin HM, Lai R, Aggarwal BB. Curcumin (diferuloylmethane) inhibits constitutive NF-kappaB activation, induces G1/S arrest, suppresses proliferation, and induces apoptosis in mantle cell lymphoma. Biochem Pharmacol, 2005; 70(5):700-13.

Shoba G, Joy D, Joseph T, Majeed M, Rajendran R, Srinivas PS. Influence of piperine on the pharmacokinetics of curcumin in animals and human volunteers. Planta Med, 1998; 64(4):353-6.

Singh AK, Jiang Y, Gupta S, Younus M, Ramzan M. Antiinflammatory potency of nano-formulated puerarin and curcumin in rats subjected to the lipopolysaccharide-induced inflammation. J Med Food, 2013; 16(10):899-911.

Soccio M, Laus MN, Flagella Z, Pastore D. Assessment of antioxidant capacity and putative healthy effects of natural plant products using soybean lipoxygenase-based methods. An overview. Molecules, 2018; 23(12):1-22.

Sreejayan, Rao MN. Curcuminoids as potent inhibitors of lipid peroxidation. J Pharm Pharmacol, 1994; 46(12):1013-6.

Surh YJ, Lee E, Lee JM. Chemoprotective properties of some pungent ingredients present in red pepper and ginger. Mutat Res, 1998; 402(1-2):259-67.

Tai FWD, McAlindon ME. NSAIDs and the small bowel. Curr Opin Gastroenterol, 2018; 34(3):175-82.

Thakur RS, Puri HS, Husain A. Major medicinal plants of India. Lucknow, India: Central Institute of Medicinal and Aromatic Plants, 1989.

Toden S, Theiss AL, Wang X, Goel A. Essential turmeric oils enhance anti-inflammatory efficacy of curcumin in dextran sulfate sodiuminduced colitis. Sci Rep, 2017; 7(814):1-12.
Tremmel L, Rho O, Slaga TJ, DiGiovanni J. Inhibition of skin tumor promotion by TPA using a combination of topically applied ursolic acid and curcumin. Mol Carcinog, 2019; 58(2):185-95.

Vanella L, Li Volti G, Distefano A, Raffaele M, Zingales V, Avola R, Tibullo D, Barbagallo I. A new antioxidant formulation reduces the apoptotic and damaging effect of cigarette smoke extract on human bronchial epithelial cells. Eur Rev Med Pharmacol Sci, 2017; 21(23):547884.

Vasileva LV, Saracheva KE, Ivanovska MV, Petrova AP, Marchev AS, Georgiev MI, Murdjeva MA, Getova DP. Antidepressant-like effect of salidroside and curcumin on the immunoreactivity of rats subjected to a chronic mild stress model. Food Chem Toxicol, 2018; 121:604-11.

Wei SY, Chen Y, Xu XY. Progress on the pharmacological research of puerarin: a review. Chin J Nat Med, 2014; 12(6):407-14.

Wolfe KL, Liu RH. Structure-activity relationships of flavonoids in the cellular antioxidant activity assay. J Agric Food Chem, 2008; 56(18):8404-11.

Wright JS. Predicting the antioxidant activity of curcumin and curcuminoids. J Mol Struct, 2002; 591(1):207-17.

Wu SJ, Tam KW, Tsai YH, Chang CC, Chao JCJ. Curcumin and saikosaponin a inhibit chemical-induced liver inflammation and fibrosis in rats. Am J Chin Med, 2010; 38(1):99-111.

Wu X, Pfalzer AC, Koh GY, Tang S, Crott JW, Thomas MJ, Meydani M, Mason JB. Curcumin and salsalate suppresses colonic inflammation and procarcinogenic signaling in high-fat-fed, azoxymethanetreated mice. J Agric Food Chem, 2017; 65(33):7200-9.

Wu Y, Antony S, Meitzler JL, Doroshow JH. Molecular mechanisms underlying chronic inflammation-associated cancers. Cancer Lett, 2014; 345(2):164-73.

Yahfoufi N, Alsadi N, Jambi M, Matar C. The immunomodulatory and anti-inflammatory role of polyphenols. Nutrients, 2018; 10(11):1-23

Yan F, Li H, Zhong Z, Zhou M, Lin Y, Tang C, Li C. Co-delivery of prednisolone and curcumin in human serum albumin nanoparticles for effective treatment of rheumatoid arthritis. Int J Nanomedicine, 2019; 14:9113-25.

Yang KY, Lin LC, Tseng TY, Wang SC, Tsai TH. Oral bioavailability of curcumin in rat and the herbal analysis from Curcuma longa by LC-MS/MS. J Chromatogr B, 2007; 853(1):183-9.

Yu W, Tao M, Zhao Y, Hu X, Wang M. 4'-methoxyresveratrol alleviated AGE-induced inflammation via RAGE-mediated NF- $\kappa \beta$ and NLRP3 inflammasome pathway. Molecules, 2018; 23(6):1-13.

Zaky A, Bassiouny A, Farghaly M, El-Sabaa BM. A combination of resveratrol and curcumin is effective against aluminum chloride-induced neuroinflammation in rats. J Alzheimer's Dis. 2017; 60(s1):221-35.

Zhang F, Altorki NK, Mestre JR, Subbaramaiah K, Dannenberg AJ. Curcumin inhibits cyclooxygenase-2 transcription in bile acid- and phorbol ester-treated human gastrointestinal epithelial cells. Carcinogenesis, 1999; 20(3):445-51.

Zhang L, Virgous C, Si H. Synergistic anti-inflammatory effects and mechanisms of combined phytochemicals. J Nutr Biochem, 2019; 69:19-30.

Zhou W, Liu Q, Zang X, Hu M, Yue Y, Wang Y, Lv C, Du Z. Combination use of tolfenamic acid with curcumin improves antiinflammatory activity and reduces toxicity in mice. J Food Biochem, 2020; 44(6):1-10.

Zhou Z, Pan C, Lu Y, Gao Y, Liu W, Yin P, Yu X. Combination of erythromycin and curcumin alleviates Staphylococcus aureus induced osteomyelitis in rats. Front Cell Infect Microbiol, 2017; 7(379):1-6.

How to cite this article:

Setiawan PYB, Kertia N, Nurrochmad A, Wahyuono S. Curcumin in combination: review of synergistic effects and mechanisms in the treatment of inflammation. J Appl Pharm Sci, 2021; 11(02):001-011. 